\title{
KEBIJAKAN SISTEM PERTANGGUNGJAWABAN PIDANA ANAK DALAM RANGKA PERLINDUNGAN HUKUM BAGI ANAK YANG BERHADAPAN DENGAN HUKUM
}

\author{
oleh: \\ Hana Krisnamurti
}

\begin{abstract}
ABSTRAK
Persoalan pelaku tindak pidana anak bukan hanya persoalan di Indonesia melainkan merupakan masalah dunia. Dalam kehidupan masyarakat di berbagai dunia terdapat perilaku anak yang dianggap menyimpang oleh masyarakat sekitarnya. Sehubungan dengan hal itu United Nations Children Fund (UNICEF) mengembangkan konsep Restorative Justice untuk melindungi anak yang berkonflik dengan hukum. Undang-Undang Sistem Peradilan Pidana Anak mengamanatkan adanya perubahan suatu paradigma berpikir yang mengutamakan kepentingan terbaik bagi anak dan perlindungan terhadap hak anak. Substansi yang paling mendasar dalam Undang-Undang ini berkaitan dengan pertanggungjawaban pidana anak yaitu pengaturan secara tegas mengenai Keadilan Restoratif (Restorative Justice) dan Diversi yang dimaksudkan untuk menghindari dan menjauhkan Anak dari proses peradilan sehingga dapat menghindari stigmatisasi terhadap Anak yang berhadapan dengan hukum.
\end{abstract}

Kata Kunci: Restorative Justice, Diversi, Perlindungan Anak

\section{PENDAHULUAN}

\section{A. Latar Belakang}

Hukum adalah rangkaian peraturan-peraturan mengenai tingkah laku manusia sebagai anggota masyarakat, yang masing-masing mempunyai kepentingan sehingga para anggota masyarakat dalam memenuhi kepentingan tersebut mengadakan hubungan-hubungan yang diatur oleh hukum dengan tujuan untuk menciptakan keseimbangan, keselamatan, kebahagiaan, dan tata tertib di dalam masyarakat.

Hukum dibuat untuk memenuhi kebutuhan manusia, oleh karea itu pelaksanaan hukum atau penegakan hukum harus memberikan manfaat dan kegunaan bagi masyarakat. B. Arif Sidharta mengatakan bahwa : "tatanan hukum yang beroperasi dalam suatu masyarakat pada dasarnya merupakan pengejawantahan cita hukum yang dianut dalam masyarakat yang bersangkutan ke dalam perangkat berbagai aturan hukum positif, lembaga hukum, dan proses (perilaku birokrasi pemerintahan dan warga masyarakat). ${ }^{1}$

Strategi sasaran pembangunan dan penegakan hukum harus ditujukan pada kualitas substantif/materiil suatu perangkat hukum, karena kualitas pembangunan dan penegakan hukum yang dituntut oleh masyarakat saat ini bukan hanya sekedar kualitas formal. Kualitas substantif seperti terungkap dalam beberapa isu sentral yang dituntut masyarakat saat ini, yaitu antara lain : adanya perlindungan hukum, tegaknya nilai kebenaran, kejujuran, keadilan, dan kepercayaan, tidak adanya penyalahgunaan kekuasaan/wewenang, penyelenggaraan pemerintahan yang bersih dan berwibawa.

Kemajuan Ilmu Pengetahuan dan Teknologi serta kemajuan pembangunan disegala bidang meliputi sosial, politik, ekonomi dan budaya membawa dampak negatif terhadap sikap dan perilaku masyarakat yang berdampak pula terhadap peningkatan kualitas dan kuantitas berbagai macam kejahatan yang merugikan dan meresahkan masyarakat. Kualitas kejahatan semakin meningkat dengan menggunakan berbagai macam cara atau modus operandi dengan memanfaatkan kemajuan IPTEK. Sedangkan kuantitas kejahatan meningkat mulai dari

${ }^{1}$ B. Arief Sidharta dalam buku Maidin Gultom, Perlindungan Hukum terhadap Anak dalam Sistem Peradilan Pidana di Indonesia, PT. Refika Aditama, Bandung, 2008, hlm. 15. 
kejahatan yang mengancam jiwa, harta kekayaan, bahkan kehormatan seseorang yang pelakunya beragam dari seorang dewasa hingga anak.

Tindak pidana yang dilakukan oleh anak semakin meningkat dan beragam, baik frekuensi maupun dalam keseriusan kualitas kejahatan. Hal ini terlihat dari banyaknya kasus yang terjadi. Komisi Perlindungan Anak Indonesia (selanjutnya disingkat KPAI) menerima 1.434 (seribu empat ratus tiga puluh empat) pengaduan kasus anak berhadapan hukum (ABH) sepanjang Tahun 2018. peningkatannya tidak terlalu signifikan jika dibandingkan dengan tahun 2017 yang berjumlah 1.403 (seribu empat ratus tiga) kasus. ${ }^{2}$ Berdasarkan Sistem Informasi Penelusuran Perkara pada Pengadilan Negeri Bandung diperoleh daftar perkara pidana anak dalam tiga tahun terakhir dapat dilihat dalam Tabel 1 berikut : 3

Tabel 1. Daftar Perkara Pidana Anak

\begin{tabular}{|c|l|c|c|c|c|}
\hline No & PERKARA PIDANA ANAK & $\mathbf{2 0 1 6}$ & $\mathbf{2 0 1 7}$ & $\mathbf{2 0 1 8}$ & JUMLAH \\
\hline 1 & PENCURIAN & 13 & 14 & 22 & 49 \\
\hline 2 & PENGEROYOKAN & 0 & 1 & 7 & 8 \\
\hline 3 & PEMBUNUHAN & 0 & 4 & 1 & 5 \\
\hline 4 & PERLINDUNGAN ANAK & 1 & 1 & 3 & 5 \\
\hline 5 & PENGANIAYAAN & 0 & 1 & 3 & 4 \\
\hline 6 & ASUSILA & 2 & 0 & 1 & 3 \\
\hline 7 & NARKOTIKA & 1 & 1 & 1 & 3 \\
\hline 8 & ANCAMAN \& PEMERASAN & 2 & 1 & 0 & 3 \\
\hline 9 & LAIN-LAIN & 0 & 2 & 2 & 4 \\
\hline & JUMLAH & $\mathbf{1 9}$ & $\mathbf{2 5}$ & $\mathbf{4 0}$ & $\mathbf{8 4}$ \\
\hline
\end{tabular}

Tabel 1 tersebut diatas menggambarkan bahwa perkara pidana anak dengan kasus pencurian menduduki urutan kesatu dengan jumlah yang paling banyak diikuti dengan kasus pengeroyokan pada urutan kedua, urutan ketiga adalah kasus pembunuhan dan perlindungan anak, urutan keempat adalah kasus penganiayaan, sedangkan kasus asusila, narkotika, serta ancaman dan pemerasan menduduki urutan kelima, urutan keenam adalah kasus lain-lain seperti kepemilikan senjata api dan kasus kesehatan.

Menyikapi hal tersebut diatas, anak harus tetap bertanggungjawab secara pidana atas perilaku yang diperbuatnya agar anak mendapatkan pembelajaran dan perubahan diri. Namun pertanggungjawaban pidana yang dimaksud tentu dengan mempertimbangkan bahwa anak merupakan amanah dan karunia Tuhan Yang Maha Esa yang memiliki harkat dan martabat sebagai manusia seutuhnya, bahwa untuk menjaga harkat dan martabatnya anak berhak mendapatkan perlindungan khusus terutama perlindungan hukum dalam sistem peradilan.

Pasal 1 Angka (3) Undang-Undang No. 11 Tahun 12 tentang Sistem Peradilan Pidana Anak (selanjutnya disebut Undang-Undang Sistem Peradilan Pidana Anak) menyatakan bahwa : "Anak yang Berkonflik dengan Hukum yang selanjutnya disebut Anak adalah anak yang telah berumur 12 (dua belas) tahun, tetapi belum berumur 18 (delapan belas) tahun yang diduga melakukan tindak pidana."

${ }^{2}$ https://nasional.kompas.com/read/2019/01/08/19381211, di akses pada Tanggal 21 Maret 2019 Pukul

${ }^{3}$ http://sipp.pn-bandung.go.id/list perkara, di akses pada Tanggal 21 Maret 2019 Pukul 22.00 WIB 
Ada 2 (dua) kategori perilaku anak yang membuat anak tersebut berkonflik dengan hukum, yaitu : ${ }^{4}$

1. Status Offender adalah perilaku kenakalan anak yang apabila dilakukan orang dewasa tidak dianggap sebagai kejahatan, seperti tidak menurut, membolos sekolah, atau kabur dari rumah.

2. Juvenile Delinquency adalah perilaku kenakalan anak yang apabila dilakukan orang dewasa dianggap kejahatan atau pelanggaran hukum.

Undang-Undang Sistem Peradilan Pidana Anak dimaksudkan untuk lebih melindungi dan mengayomi anak, dan memberikan kesempatan kepada anak untuk mendapatkan pembinaan mental, moral, sehingga menjadi pribadi yang mandiri, bertanggungjawab, dan berguna bagi diri sendiri, keluarga, masyarakat, bangsa, dan negara.

Undang-Undang Sistem Peradilan Pidana Anak mengamanatkan adanya perubahan suatu paradigma berpikir yang mengutamakan kepentingan terbaik bagi anak dan perlindungan terhadap hak anak. Substansi yang paling mendasar dalam Undang-Undang ini berkaitan dengan pertanggungjawaban pidana anak yaitu pengaturan secara tegas mengenai Keadilan Restoratif (Restorative Justice) dan Diversi yang dimaksudkan untuk menghindari dan menjauhkan Anak dari proses peradilan sehingga dapat menghindari stigmatisasi terhadap Anak yang berhadapan dengan hukum dan diharapkan Anak dapat kembali ke dalam lingkungan sosial secara wajar.

KPAI menyusun pedoman mengenai pelaksanaan Pemantauan, Evaluasi, dan Pelaporan Sistem Peradilan Pidana Anak yang diatur dalam peraturan KPAI sebagaimana tergambar dalam diagram alur dibawah ini $:^{5}$

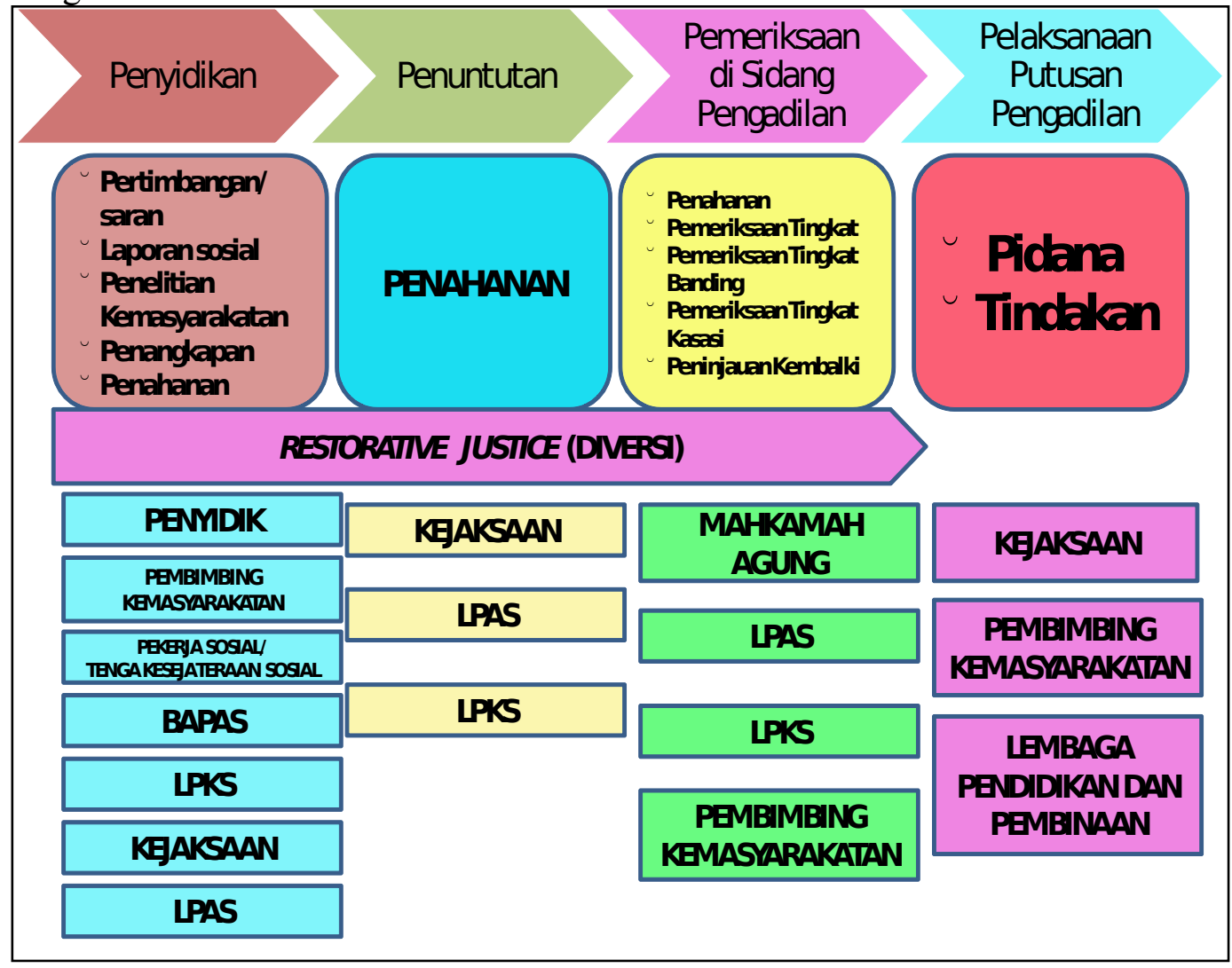

${ }^{4}$ Purnianti, Mamik Sri Supatmi, dan Ni Made Martini Tinsuk dalam Harrys Pratama Teguh, Teori dan Praktek Perlindungan Anak dalam Hukum Pidana, Penerbit Andi, Yogyakarta, 2018, hlm. 81-82.

5https: / / www.bphn.go.id/data/documents/20160914_kpai_wasmonev_sppa_fgd_pidana_an ak..pdf, diakses pada Tanggal 23 Maret 2019 Pukul 15.00 WIB. 


\section{Gambar 1. Pemantauan, Evaluasi, dan Pelaporan Sistem Peradilan Pidana Anak}

Keadilan Restoratif adalah penyelesaian perkara tindak pidana dengan melibatkan pelaku, korban, keluarga pelaku/korban, dan pihak lain yang terkait untuk bersama-sama mencari penyelesaian yang adil dengan menekankan pemulihan kembali pada keadaan semula, dan bukan pembalasan (Pasal 1 Angka (6) Undang-Undang Sistem Peradilan Pidana Anak). Proses keadilan restoratif pada dasarnya dilakukan melalui upaya diversi yang dilakukan oleh pihak kepolisian ketika kasus anak telah dilaporkan di kepolisian dengan menggunakan otoritas diskresi. Diversi yaitu pengalihan penyelesaian perkara Anak dari proses peradilan pidana ke proses di luar peradilan pidana (Pasal 1 Angka (7) Undang-Undang Sistem Peradilan Pidana Anak).

\section{B. Permasalahan}

Permasalahan yang dianalisis dalam penelitian ini adalah tentang pertimbangan hukum para penegak hukum dalam memberikan upaya diversi terhadap anak yang berkonflik dengan hukum dan Pengaruh Kebijakan Sistem Pertanggungjawaban Pidana Anak Dalam Rangka Perlindungan Hukum Bagi Anak terhadap Statistik Kriminal yang dilakukan anak

\section{PEMBAHASAN}

\section{A. Pertimbangan hukum para penegak hukum dalam memberikan upaya diversi terhadap anak yang berkonflik dengan hukum}

Pasal 1 Angka 3 Undang-Undang Sistem Peradilan Pidana Anak menyatakan Anak yang berkonflik dengan hukum yang selanjutnya disebut Anak adalah anak yang telah berumur 12 (dua belas) tahun, tetapi belum berumur 18 (delapan belas) tahun yang diduga melakukan tindak pidana. Anak yaitu periode diantara kelahiran dan permulaan kedewasaan, masa ini merupakan masa perkembangan hidup, juga masa dalam keterbatasan untuk membahayakan orang lain. Seseorang dikatakan anak atau dewasa dilihat dari umur dan aktivitas atau kemampuan berpikirnya. Oleh karena itu anak tidak dapat dikenakan pertanggungjawaban pidana secara penuh, karena seorang anak masih mempunyai keterbatasan kemampuan berpikir, dalam interval usia seorang anak terdapat perbedaan aktivitas dan pola pikir anak-anak (childhood) dan dewasa (adulthood).

Perlindungan terhadap anak yang berkonflik dengan hukum adalah sebagai upaya untuk melindungi anak dan hak-haknya agar bisa tumbuh dan berkembang secara optimal tanpa kekerasan dan diskriminasi. Perkembangan kejahatan yang semakin meningkat tentunya sangat memprihatinkan, namun menurut ketentuan peraturan perundang-undangan dalam proses peradilan pidana anak, hak-hak anak harus tetap mendapatkan perlindungan dari setiap tingkatan proses peradilan pidana anak. Perlindungan diberikan sebagai salah satu bentuk penghormatan hak asasi anak. Dalam perkembangannya proses perlindungan terhadap anak yang berkonflik dengan hukum mengalami perubahan yang mendasar, yaitu pengaturan secara tegas mengenai keadilan restoratif dan diversi. Undang-Undang Sistem Peradilan Pidana Anak dengan tegas menyatakan bahwa Sistem Peradilan Pidana Anak wajib mengutamakan pendekatan Keadilan Restoratif melalui suatu proses diversi (Pasal 5).

Restorative Justice is a process whereby all the parties with a staken in a particular offense come together to resolve collectively how to deal with the aftermath of the offense and its implications for the future (keadilan restoratif adalah proses dimana semua pihak dengan kepemilikan kepentingan dalam suatu pelanggaran tertentu datang bersama-sama untuk menyelesaikan secara kolektif bagaimana menghadapi akibat dari pelanggaran dan implikasinya untuk masa depan). ${ }^{6}$

6 Tonny Marshall dalam Edi Setiadi dan Kristian, Sistem Peradilan Pidana terpadu dan Sistem Penegakan Hukum di Indonesia, Prenadamedia Group, Jakarta, 2017, hlm. 205. 
Dengan menggunakan konsep Restorative Justice sebagaimana dikembangkan UNICEF, kiranya Peradilan Pidana Anak dapat diharapkan menghasilkan hal-hal sebagai berikut : ${ }^{7}$

1. Berkurangnya jumlah anak-anak yang dikenakan penahanan sementara dan di vonis penjara

2. Menghapuskan stigmatisasi dan mengembalikan anak menjadi manusia normal sehingga diharapkan dapat berguna kelak dikemudian hari;

3. Anak yang melakukan tindak pidana dapat menyadari kesalahannya dan bertanggungjawab, sehingga dapat diharapkan untuk tidak mengulangi lagi perbuatannya;

4. Mengurangi beban kerja pengadilan;

5. Menghemat keuangan negara;

6. Meningkatkan dukungan orang tua dan peran serta masyarakat dalam mengatasi kenakalan anak;

7. Pengintegrasian kembali anak ke dalam masyarakat.

Secara umum diversi adalah pengalihan penanganan kasus-kasus anak yang diduga telah melakukan tindak pidana dari proses formal dengan atau tanpa syarat. Penanganan anak pelaku delinkuen sebagaimana dikehendaki dalam Commentary Rule 11 Resolusi PBB 40/33, UN Standard Minimum Rule for the Administration of Juvenile Justice. Diversi sangat penting untuk diperhatikan dalam penanganan anak pelaku delinkuen, diversi dapat menghindarkan anak dari proses stigmatisasi yang lazimnya terjadi dalam proses pemidanaan anak lewat sistem peradilan pidana anak. ${ }^{8}$

Pasal 7 Undang-Undang Sistem Peradilan Pidana Anak menyatakan :

(1) Pada tingkat penyidikan, penuntutan, dan pemeriksaan perkara Anak di pengadilan negeri wajib diupayakan Diversi.

(2) Diversi sebagaimana dimaksud pada ayat (1) dilaksanakan dalam hal tindak pidana yang dilakukan:

a. diancam dengan pidana penjara di bawah 7 (tujuh) tahun; dan

b. bukan merupakan pengulangan tindak pidana

Pasal 96 Undang-Undang Sistem Peradilan Pidana Anak menyatakan pula bahwa : "Penyidik, Penuntut Umum, dan Hakim yang dengan sengaja tidak melaksanakan kewajiban sebagaimana dimaksud dalam Pasal 7 ayat (1) dipidana dengan pidana penjara paling lama 2 (dua) tahun atau denda paling banyak Rp. 200.000.000,00 (dua ratus juta rupiah)."

Keberadaan kedua pasal tersebut diatas menjadi pertimbangan hukum para penegak hukum terutama penyidik dalam melaksanakan proses diversi terhadap anak yang berkonflik dengan hukum. Namun menurut peneliti akan lebih tepat jika para penegak hukum mempertimbangkan alasan lain saat akan memberikan upaya diversi terhadap anak yang berkonflik dengan hukum yaitu dengan memperhatikan kualitas kejahatan yang dilakukan oleh anak tersebut.

Keberadaan Pasal 7 dan Pasal 9 Undang-Undang Sistem Peradilan Pidana menurut peneliti dapat dikatakan bahwa proses peradilan pidana selama ini lebih mengutamakan perlindungan terhadap pelaku tindak pidana daripada perlindungan terhadap korban. Sementara dapat dipastikan bahwa korbanlah yang mengalami kerugian akibat dari suatu tindak pidana. Kerugian yang dialami korban tersebut berdampak sangat luas bagi korban, tidak hanya mengalami kerugian materil saja tetapi juga kerugian immateril. Proporsi

7 Wagiati Soetedjo dan Melani, Hukum Pidana Anak, Refika Aditama, Bandung, 2017, hlm. 136.

${ }^{8}$ Lilik Mulyadi, Wajah Sistem Peradilan Anak, Alumni, Bandung, 2014, hlm. 111. 
perlindungan yang tidak seimbang tentu berdampak kepada ketidakadilan yang diterima korban.

Pendekatan law and order atau hukum dan ketertiban yang mendominasi penegakan hukum ternyata dalam praktik menimbulkan dampak yang dilematis bahkan konsepsi tersebut dipandang sebagai contradictio in terminis. Pengertian hukum secara implisit mengandung pembatasan oleh undang-undang dan suatu prosedur yang seharusnya ditempuh untuk mencapai ketertiban. Konsep ketertiban berdasarkan hukum dengan sendirinya telah menempatkan cita harmonisasi berada di bawah konsep legalitas.

Pendekatan hukum dan ketertiban yang bertumpu pada asas legalitas telah menimbulkan penafsiran ganda bagi petugas kepolisian. Kedua penafsiran tersebut adalah :

1. Penggunaan hukum sebagai instrumen dari ketertiban dimana hukum pidana berisikan perangkat hukum untuk memelihara ketertiban dalam masyarakat; dan

2. Penggunaan hukum sebagai pembatas bagi petugas penegak hukum dalam melaksanakan tugasnya atau dengan kata lain hukum pidana bertugas melindungi kemerdekaan individu dalam kerangka suatu sistem ketertiban masyarakat.

Mengutip pendapat Romli Atmasasmita tentang ciri pendekatan hukum dan ketertiban (law and order) dalam peradilan pidana ialah :

1. Kepribadian ganda :

a. Penggunaan hukum sebagai instrumen ketertiban dalam masyarakat; dan

b. Penggunaan hukum sebagai pembatas kekuasaan penegak hukum

2. Titik berat pada law enforcement dimana hukum diutamakan dengan dukungan instansi kepolisian

3. Keberhasilan penanggulangan kejahatan sangat tergantung pada efektivitas dan efisiensi tugas kepolisian.

4. Menimbulkan ekses diskresi dalam pelaksanaan tugas kepolisian : police brutality;kolusi; police corruption.

Penegakan hukum pada hakikatnya mengandung supremasi nilai substansial, yaitu nilai keadilan. Seringkali publik memberikan komentar yang beragam mengenai penegakan hukum dan keadilan yang diasosiasikan dengan apa yang dihasilkan oleh lembaga peradilan sehingga peradilan merupakan simbolisasi dari upaya melahirkan penegakan hukum yang pro-keadilan, sementara perhatian yang lebih penting terpusat pada peran aparatur penegak hukum yang mengoperasikan fungsi peradilan menjadi lebih konkret.

Secara yuridis peradilan merupakan kekuasaan kehakiman yang berbentuk badan peradilan. Dalam peradilan terkait beberapa lembaga yaitu kepolisian, kejaksaan, kehakiman, lembaga pemasyarakatan, bantuan hukum dalam mewujudkan perlindungan, dan keadilan bagi setiap warga negara. B. Arief Sidharta mengatakan bahwa peradilan adalah pranata (hukum) untuk secara formal, imparsial-objektif serta adil manusiawi, memproses penyelesaian definitif yang hasilnya dirumuskan dalam bentuk sebuah putusan yang disebut vonis, dan yang implementasinya dapat dipaksakan dengan menggunakan aparat negara (artinya mengingat semua pihak secara hukum) terhadap konflik antar subjek hukum, termasuk konflik antar warga masyarakat dan badan hukum publik (pemerintah).

Peranan kebijakan/kewenangan penjatuhan pidana yang pada hakikatnya juga berarti penerapan kebijakan/kewenangan penegakan hukum pidana melalui beberapa tahap/proses yaitu penyidikan, penuntutan, pemidanaan, pelaksanaan/eksekusi pidana, merupakan satu kesatuan sistem penegakan hukum pidana yang integral. Keseluruhan sistem/proses/kewenangan penegakan hukum pidana tersebut harus terwujud dalam satu kesatuan kebijakan legislatif yang integral. 
Penegakan hukum yang benar dan adil harus bertitik tolak dari postulat peradaban, kemasyarakatan, kepatutan. Hanya penegakan hukum yang mengandung nilai-nilai peradaban dan kemanusiaan dan kepatutan yang dapat mencapai kebenaran (truth) dan keadilan (justice). Setiap penegakan hukum bertitik tolak dari nilai-nilai peradaban, kemanusiaan, dan kepatutan, mendekati kebenaran dan keadilan. Penegakan hukum bukan semata-mata menegakan peraturan perundang-undangan dan hukum saja, tetapi harus ditujukan untuk menegakkan kebenaran dan keadilan (to enforce the truth and justice) alasannya adalah sesuatu yang wetmatig (legal) belum tentu rechtvaardig (just), sesuatu yang rechtmatig (lawful) belum tentu rechtvaardig (just), akan tetapi sesuatu yang sesuai dengan nilai-nilai peradaban dan kemanusiaan dan kepatutan pasti mengandung nilai-nilai kebenaran dan keadilan. Setiap nilai kemanusiaan, peradaban, dan kepatutan yang sesuai dengan keadaan tempat, lingkungan, dan waktu dimana masyarakat yang bersangkutan hidup, dirasakan anggota masyarakat benarbenar tepat dan adil.

Hak-hak anak dalam proses peradilan dipahami sebagai suatu perwujudan keadilan. Keadilan dalam hal ini ialah suatu kondisi yang setiap anak dapat melaksanakan hak dan kewajibannya secara seimbang (yang mengembangkan manusia seutuhnya yang berbudi luhur). Dalam konteks anak yang berhadapan dengan hukum Undang-Undang Perlindungan Anak menyatakan bahwa pemerintah, pemerintah daerah, dan lembaga negara lainnya berkewajiban dan bertanggungjawab untuk memberikan perlindungan khusus kepada anak yang berhadapan dengan hukum. Undang-Undang Sistem Peradilan Pidana Anak menyatakan yang dimaksud dengan anak yang berhadapan dengan hukum (children in conflict with the law) bukan hanya anak yang berkonflik dengan hukum melainkan juga termasuk anak yang menjadi korban tindak pidana dan anak yang menjadi saksi tindak pidana (Pasal 1 Ayat (2)). Oleh karena itu menurut peneliti para penegak hukum terutama penyidik harus betul-betul memperhatikan keseimbangan perlindungan hukum terhadap anak yang berkonflik dengan hukum maupun anak yang menjadi korban tindak pidana.

Peneliti berpendapat bahwa kiranya pemahaman terhadap perundang-undangan yang terkait sangat diperlukan. Penegak Hukum perlu memahami dengan benar amanat dan prinsip yang disampaikan dalam Pasal 7 Undang-Undang Sistem Peradilan Pidana Anak dalam pertimbangan hukumnya memberikan upaya diversi terhadap anak berkonflik dengan hukum.

Upaya pelaksanaan diversi tidak berarti bahwa semua perkara anak harus dijatuhkan putusan berupa tindakan dikembalikan kepada orang tua, penegak hukum tentunya harus mempertimbangkan kriteria-kriteria tertentu, antara lain:

1. anak tersebut baru pertama kali melakukan kenakalan (first offender);

2. anak tersebut masih sekolah;

3. tindak pidana yang dilakukan bukan tindak pidana kesusilaan yang serius, tindak pidana yang mengakibatkan hilangnya nyawa, luka berat atau cacat seumur hidup, atau tindak pidana yang mengganggu/merugikan kepentingan umum.

Para penegak hukum harus memahami dengan benar pengertian dan tujuan dari diversi sebelum melakukan diversi. Apabila para penegak hukum melakukan upaya diversi sebagai tugas maka penegak hukum harus dapat mengambil tindakan yang tepat berkaitan dengan tindakan diversi, apabila tidak maka akan menimbulkan sikap apriori bagi masyarakat, baik korban maupun pelaku. Akibatnya masyarakat akan menghindari proses diversi, karena beranggapan ada ketimpangan dalam pelaksanaannya dan diversi sebagai kesewenangwenangan penegak hukum dalam menerjemahkan kekuasaannya.

Peneliti berpendapat para penegak hukum ketika menjalankan tugasnya dalam memberikan upaya diversi hendaknya tidak selesai pada penandatanganan kesepakatan diversi diantara kedua belah pihak namun para penegak hukum harus memiliki fungsi pengawasan terhadap dilaksanakannya semua kesepakatan oleh pelaku. Penegak hukum harus mengawal hingga hak korban benar-benar terpenuhi, yaitu pelaku benar-benar memberikan 
tanggungjawab langsung kepada korban dalam bentuk ganti rugi atau pertanggungjawaban lainnya selain pidana.

\section{B.Pengaruh Kebijakan Sistem Pertanggungjawaban Pidana Anak Dalam Rangka Perlindungan Hukum Bagi Anak terhadap Statistik Kriminal yang dilakukan anak}

Kebijakan penanggulangan kejahatan dapat ditempuh dengan penerapan hukum pidana (criminal law application), pencegahan tanpa pidana (prevention without punishment), dan memengaruhi pandangan masyarakat mengenai kejahatan dan pemidanaan (influencing views of society on crime and punishment). Dengan demikian upaya penanggulangan kejahatan secara garis besar terbagi dua yaitu melalui jalur hukum pidana (penal) dan diluar jalur hukum pidana (non penal).

Upaya penanggulangan kejahatan melalui jalur penal lebih menitikberatkan pada sifat represif (pemberantasan) sedangkan jalur non penal lebih menitikberatkan pada sifat preventif (pencegahan) sebelum kejahatan terjadi. Mengingat upaya penanggulangan kejahatan melalui jalur non penal lebih bersifat tindakan pencegahan untuk terjadinya kejahatan, maka sasaran utamanya adalah menangani faktor-faktor kondusif penyebab terjadinya kejahatan. Faktorfaktor kondusif ini antara lain berpusat pada masalah-masalah atau kondisi-kondisi sosial yang secara langsung atau tidak langsung dapat menimbulkan atau menumbuhsuburkan kejahatan.

Upaya penanggulangan secara non penal seperti diuraikan diatas dewasa ini ditempuh melalui kebijakan Sistem Pertanggungjawaban Pidana Anak dengan restorative justice melalui proses Diversi. Pelaksanaan restorative justice melalui proses diversi memberikan dukungan terhadap proses perlindungan terhadap anak yang berkonflik dengan hukum. Sesuai dengan prinsip utama dari diversi yaitu menghindari pelaku tindak pidana dari sistem peradilan pidana formal dan memberikan kesempatan kepada anak sebagai pelaku untuk menjalankan sanksi alternatif tanpa pidana penjara.

Salah satu isu yang harus diperhatikan dari hasil diversi adalah beberapa akibat (impact) terutama perilaku pelaku setelah pertanggungjawabannya selesai dilaksanakan, yaitu dapat mengurangi pelanggaran kembali (re-offending) oleh pelaku yang telah menjalani diversi.

Keberadaan Undang-Undang Sistem Peradilan Pidana Anak yang mewajibkan upaya diversi di setiap tingkatan proses peradilan pidana menunjukan fenomena tidak terdapat perbedaan yang cukup berarti ketika anak pelaku tindak pidana diberikan upaya diversi dengan pemenjaraan. Hal ini terlihat dalam Data statistik kriminal yang peneliti uraikan dalam latar belakang menggambarkan bahwa statistik kriminal yang dilakukan oleh anak semakin meningkat dari tahun ke tahun. Namun perbandingan jumlah re-offending setelah diversi dan pemenjaraan tidaklah serta merta menunjukan kemandulan proses diversi karena masih ada faktor-faktor lain yang menjadi penyebab re-offending dari proses diversi.

Pelaksanaan restorative justice melalui proses diversi sudah terlihat dan mempunyai pengaruh positif dalam penegakan hukum perlindungaan anak agar anak tidak terkena stigmatisasi pelaku kriminal yang pernah di hukum atau pelanggar hukum negara secara terus menerus. Faktor lain yang mempengaruhi hasil diversi diantaranya adalah pengawasan dari orangtua dan keluarga untuk mengubah perilaku anak dari perilaku melanggar (offence behaviour) dapat dijadikan faktor penentu yang cukup berarti.

Naik turunnya kejahatan di suatu negara tidaklah berhubungan dengan perubahanperubahan di dalam hukumnya atau kecenderungan-kecenderungan dalam putusaan pengadilan/kebijakan para penegak hukum, tetapi berhubungan dengan bekerjanya atau berfungsinya perubahan-perubahan kultur yang besar dalam kehidupan masyarakat. Kultur hukum adalah opini-opini, kepercayaan-kepercayaan (keyakinan-keyakinan), kebiasaankebiasaan, cara berpikir dan cara bertindak, baik dari para penegak hukum maupun dari warga masyarakat tentang hukum dan berbagai fenomena yang berkaitan dengan hukum. 
Bekerjanya hukum pidana harus dilihat dari keseluruhan konteks kulturnya. Ada saling pengaruh antara hukum dengan faktor-faktor lain yang membentuk sikap dan tindakantindakan.

Pengaruh pidana terhadap si pelanggar dapat saja diketahui pengaruhnya namun pengaruh-pengaruhnya terhadap masyarakat luas sangat sulit di ukur karena merupakan terra incognita suatu wilayah yang tidak diketahui (unknown territory)

Sangat sulit untuk melakukan evaluasi terhadap efektivitas dari general deterrence karena mekanisme pencegahan (deterrence) itu tidak diketahui, tidak dapat diketahui hubungan yang sesungguhnya antara sebab dan akibat. Orang mungkin melakukan kejahatan atau mungkin mengulanginya lagi tanpa ada hubungan dengan ada tidaknya undang-undang atau pidana yang dijatuhkan. Efektivitas hukum pidana tidak dapat diukur secara akurat. Sarana-sarana kontrol sosial lainnya seperti kekuasaan orang tua, kebiasaan, keyakinan agama, dukungan, merupakan sarana yang lebih efisien dalam mengatur tingkah laku manusia sehingga dapat mencegah perbuatan yang sama kuatnya dengan ketakutan orang pada pidana.

Berdasarkan uraian-uraian tersebut diatas cukup beralasan untuk terus menerus menggali, memanfaatkan dan mengembangkan upaya-upaya non penal untuk mengimbangi kekurangan dan keterbatasan sarana penal. Upaya non penal yang paling stategis adalah segala upaya untuk menjadikan masyarakat sebagai lingkungan sosial dan lingkungan hidup yang sehat secara materiil dan immateriil dari faktor-faktor kriminogen.

Upaya-upaya non penal dapat ditempuh dengan menyehatkan masyarakat melalui kebijakan sosial dan dengan menggali berbagai potensi yang ada di dalam masyarakat itu sendiri. Yang digali dari berbagai sumber yang mempunyai potensi efek preventif. Misalnya melalui media massa, pemanfaatan teknologi, dan pemanfaatan potensi efek preventif dari aparat penegak hukum.

\section{PENUTUP}

\section{A. Kesimpulan}

Proses peradilan pidana selama ini lebih mengutamakan perlindungan terhadap pelaku tindak pidana daripada perlindungan terhadap korban, sedangkan kerugian yang dialami berdampak sangat luas bagi korban, tidak hanya mengalami kerugian materil saja tetapi juga kerugian immateril. Proporsi perlindungan yang tidak seimbang tentu berdampak kepada ketidakadilan yang diterima korban.

Perbandingan jumlah re-offending setelah diversi dan pemenjaraan tidaklah serta merta menunjukan kemandulan proses diversi karena masih ada faktor-faktor lain yang menjadi penyebab re-offending dari proses diversi. Pelaksanaan restorative justice melalui proses diversi sudah terlihat dan mempunyai pengaruh positif dalam penegakan hukum perlindungaan anak agar anak tidak terkena stigmatisasi pelaku kriminal yang pernah di hukum.

\section{B. Saran}

Perlu adanya unsur kehati-hatian bagi penegak hukum saat melakukan pertimbangan hukum sehingga akan tercipta keseimbangan perlindungan hukum baik terhadap anak pelaku tindak pidana maupun anak sebagai korban tindak pidana. Perlu terus menerus menggali, memanfaatkan dan mengembangkan upaya-upaya non penal dalam menangani perkara anak untuk mengimbangi kekurangan dan keterbatasan sarana penal. 


\section{DAFTAR PUSTAKA}

Arief Sidharta dalam buku Maidin Gultom, Perlindungan Hukum terhadap Anak dalam Sistem Peradilan Pidana di Indonesia, PT. Refika Aditama, Bandung, 2008.

Lilik Mulyadi, Wajah Sistem Peradilan Anak, Alumni, Bandung, 2014.

Purnianti, Mamik Sri Supatmi, dan Ni Made Martini Tinsuk dalam Harrys Pratama Teguh, Teori dan Praktek Perlindungan Anak dalam Hukum Pidana, Penerbit Andi, Yogyakarta, 2018.

Tonny Marshall dalam Edi Setiadi dan Kristian, Sistem Peradilan Pidana terpadu dan Sistem Penegakan Hukum di Indonesia, Prenadamedia Group, Jakarta, 2017.

Wagiati Soetedjo dan Melani, Hukum Pidana Anak, Refika Aditama, Bandung, 2017.

https://nasional.kompas.com/read/2019/01/08/19381211, di akses pada Tanggal 21 Maret 2019 Pukul 21.00 WIB

http://sipp.pn-bandung.go.id/list perkara, di akses pada Tanggal 21 Maret 2019 Pukul 22.00 WIB

https://www.bphn.go.id/data/documents/20160914 kpai wasmonev sppa fgd pidana anak.. pdf, diakses pada Tanggal 23 Maret 2019 Pukul 15.00 WIB. 